\title{
Deslocamento dorsal bilateral de escápula em bovino - relato de caso
}

Uila Almeida Aragão de Alcantara ${ }^{[a] "}$, Tatiane Vitor da Silva ${ }^{[b]}$, Rodolpho Almeida Rebouças ${ }^{[c]}$, Nivaldo de Azevedo Costa $a^{[b]}$, Maria Isabel de Souza[b], Luiz Teles Coutinho ${ }^{[b]}$, Jobson Filipe de Paula Cajueiro ${ }^{[b]}$, Rodolfo José Cavalcanti Souto ${ }^{[b]}$, Carla Lopes de Mendonça $a^{[b]}$, José Augusto Bastos Afonso ${ }^{[b]}$

\footnotetext{
[a] Programa de Pós-Graduação em Sanidade e Reprodução de Ruminantes, Universidade Federal Rural de Pernambuco (UFRPE), Garanhuns, PE, Brasil

[b] Clínica de Bovinos, Universidade Federal Rural de Pernambuco (UFRPE), Garanhuns, PE, Brasil

[c] Programa de Pós-Graduação em Medicina Veterinária, Universidade Federal Rural de Pernambuco (UFRPE), Garanhuns, PE, Brasil
}

*Autor correspondente

e-mail: uilaaragao@gmail.com

\section{Resumo}

As afecções conhecidas como ombros caídos ou flying scapula (escápula voadora) são consideradas raras, geralmente ocorrendo quando há ruptura ou dano do músculo serrátil ventral. Frequentemente acometem animais com idade entre 6 a 18 meses, associadas à distrofia muscular nutricional. Porém, podem se manifestar em animais mais velhos. Deficiência de vitamina E e/ou selênio tem sido associada a essa enfermidade. No entanto, alguns autores não observaram relação entre a deficiência de vitamina E e/ou selênio e a lesão, atribuindo ao exercício excessivo. Os animais acometidos apresentam andar rígido, relutância em se locomover, edema na região axilar. Devido às poucas descrições desta enfermidade, o objetivo desse relato foi descrever os achados clínico-laboratoriais de uma novilha. Um bovino, fêmea, mestiça, 6 meses de idade aproximadamente, pesando em média 170 kg foi atendido na Clínica de Bovinos de Garanhuns, da Universidade Federal Rural de Pernambuco (CBG-UFRPE). Na anamnese, o proprietário relatou que mudou o animal de pasto, onde havia outros animais de diferentes faixas etárias, e após três dias da mudança de ambiente observou posição anormal das escápulas, suspeitando que o animal tivesse sido montado por outro. Desde então apresentava perda de apetite e apatia. Os animais eram criados em sistema extensivo, a alimentação era constituía por capim Buffel (Cenchrus ciliaris L.) e suplementação mineral ad libitum. 0 animal foi examinado seguindo as recomendações de Dirksen et al. (1993). Dentre os achados observou-se escore corporal regular, pelos eriçados e sem brilho, taquipneia e polipneia, taquicardia, anorexia. As principais alterações clínicas encontradas estavam limitadas ao sistema musculoesquelético. 0 animal apresentava dificuldade para se levantar e relutância para se 
locomover; ao passo, as escápulas pareciam soltas, num plano acima das vértebras torácicas, com perceptível afundamento da caixa torácica entre os membros anteriores. 0 hemograma evidenciou hipoproteinemia (5,2 g/dL). Na bioquímica clínica, o valor de creatinina quinase (CK) estava elevado (898 U/L) e as dosagens de vitamina $\mathrm{E}(7,8 \mathrm{mg} / \mathrm{dL})$ e selênio $(75,40 \mathrm{mcg} / \mathrm{mL})$ estavam acima dos valores normais para a espécie. 0 proprietário optou por levar o animal de volta à fazenda; sendo assim, foi estabelecido o tratamento clínico conservador fazendo-se o uso de anti-inflamatórios não esteroidais (fenilbutazona, $4 \mathrm{mg} / \mathrm{kg}$, via intramuscular, 24/24 horas, cinco aplicações), e mantendo-se o animal em um piquete isolado e confortável. Deslocamento escapular é uma condição rara em bovinos e sua origem pode estar associada a deficiências minerais ou lesões traumáticas. Diante do histórico, a forma abrupta da doença e os achados clínico-laboratoriais, o presente relato possivelmente trata-se de uma lesão traumática que ocasionou o deslocamento dorsal bilateral da escápula. 